\title{
Dispute Settlement Orders Under Australia's Workplace Relations Act 1996: Are They Working?
}

\section{Graeme Watson}

$\mathrm{L}$

ABOUR market reform is widely recognised as an essential component in broader economic reform. Reforms of federal and State industrial legislation in the 1990s have involved a change in focus from a centralised system based on awards and arbitration to enterprise bargaining with awards operating as a general safety net.

The Workplace Relations and other Legislation Amendment Act 1996 was one of the major reforms of the Howard Government in that year. One component of the reforms was the enhancement of powers of the Australian Industrial Relations Commission (AIRC) to issue orders to stop or prevent industrial action, along with the ready enforcement of such orders by way of injunction in the Federal Court.

Enforcement of dispute settlement orders has had a chequered history in Australia. Mechanisms have always been available to make orders that industrial action cease or not occur; but such orders have been either observed in the breach or granted in very exceptional circumstances. Former ACTU Legal Officer Professor Breen Creighton (1991) has described this situation as a paradox within the Australian industrial system. In practice, it has represented a serious imbalance that has undermined the standing of the Australian system and its institutions. A system which imposes enforceable obligations on employers yet makes largely ineffective recommendations, directions and orders against industrial action by trade unions has been widely criticised. The issue is of critical importance to the evolution of the AIRC towards playing a less interventionist role in 'interest' disputes (disputes over claims for improved entitlements) while retaining an important role in the proper settlement of 'rights' disputes (disputes over compliance with existing entitlements).

Effective dispute settlement powers are most important in the case of irresponsible wildcat stoppages, especially in industry sectors of major economic significance and in which unions engage in militant industrial behaviour generally over managerial decision-making. More effective dispute settlement powers could also help improve Australia's record on industrial disputes. Although the number of working days lost through industrial action dropped through the 1970s and the 1980s in common with the rest of the western industrialised world, it remains above the OECD average. Whereas the annual average number of working days lost in OECD countries during 1990-96 was 85 per 1,000 employees, in Australia the equivalent number was 143 (Sweeney \& Davies, 1997). 
In this note, some of the experiences of the revised dispute settlement power during its first twelve months of operation are briefly examined. It is argued that further reforms are needed to remove the significant discretion enjoyed by the AIRC and the Federal Court in making and enforcing dispute settlement orders.

\section{The New Dispute Settlement Power}

The 1996 amendments provide for enhanced dispute settlement powers under a revised Section 127 of the Workplace Relations Act. This section replaces previous provisions allowing 'bans clauses' to be inserted into awards by presidential members and full benches of the AIRC and little-used provisions relating to the public service. Section 127 is a broad power, vested in all members of the AIRC, to issue orders prohibiting any industrial action which is occurring, threatened, impending or probable. The AIRC is empowered to make orders on its own initiative, or on application by parties to an industrial dispute, by persons who are directly affected or likely to be directly affected by the industrial action or by organisations with members directly affected or likely to be directly affected. The AIRC is required to hear and determine an application as quickly as practicable. Compliance with an order is expressed as a statutory obligation; and the Federal Court may grant injunctions, including interim injunctions, if it is satisfied that the order has been contravened or if conduct is proposed which would involve such a contravention. The extension of the power to all members of the AIRC and its ready enforcement through Federal Court injunctions were no doubt intended to ensure that the exercise of such powers was not confined to exceptional or unusual circumstances and so would provide an effective remedy against irresponsible industrial action (Reith, 1996).

\section{Experience of the New Laws}

The experience of applications lodged under s.127 in the first twelve months is mixed. On some occasions the AIRC has promptly and effectively dealt with matters before it. But on other occasions the provision has operated unsatisfactorily.

The Mobil Oil case. The first application under s.127 was made by Mobil Oil on 31 December 1996, the first day the section became available. The dispute related to the remobilisation of a construction project to install a new catalytic cracker unit at the Altona refinery in Victoria. Unions banned the project over demands that employees previously engaged through another contractor be employed on the project. The ban prevented work on the site restarting. The orders that the AIRC had issued in December 1996 under its previous general powers had been ignored by the unions. Nevertheless, the AIRC granted the unions a further adjournment, and hearings were ultimately conducted on 8 and 9 January 1997. Orders were issued on 17 January, but the unions ignored them and proceedings were initiated in the Federal Court to enforce the orders. These proceedings were delayed and the Court deferred applications for interim injunctions in order to allow the AIRC 
to make further attempts to broker a compromise. Eventually, in view of the persistence of certain continuing problems, limited injunctions were granted in June 1997.

As this case shows, significant delays can occur even when major projects are held up by industrial action and when the legislation requires the AIRC to act expeditiously. The approach of the AIRC and the Federal Court demonstrates a lingering reluctance to make orders against industrial action and an apparent preference for doing so only in exceptional circumstances or as a last resort.

The Coal \& Allied cases. In early 1997, Coal \& Allied, a subsidiary of Rio Tinto, attempted to use s.127 to bring about more responsible industrial behaviour and adherence to dispute settlement procedures in awards and agreements at the Hunter Valley No. 1 Coal Mine in New South Wales. The Company produced evidence to demonstrate that 14 24-hour stoppages occurred in 1996, both against management decisions and associated AIRC decisions and as part of national or statewide stoppages over political issues. A further 24-hour stoppage in breach of the dispute settlement procedure in the award occurred in January 1997, when two employees were issued diary notes for minor breaches of the Company's code of conduct. This stoppage prompted the Company to apply for an order prohibiting future industrial action inconsistent with the disputes procedure in the award. Proceedings began in January 1997, and on the unions' application were referred by the President to a full bench of the AIRC for hearing and determination. The full bench sat on six hearing days between March and May 1997, and on 20 June 1997 granted an order against industrial action in breach of the disputes procedure. The order was directed towards local industrial action in protest against, or to secure the reversal or non-implementation of, a decision made in the reasonable exercise of an available award right or managerial discretion.

The full bench made the following comments about such industrial action:

Local unprotected industrial action of the kind we have described was not comprehensively defended in Mr Kelly's (CFMEU) evidence. We do not consider that such industrial action can reasonably be defended. Industrial reaction to disciplinary measures is not defensible or legitimate when review and grievance procedures are now so readily available. Resort to industrial action in a manner that pays little or no regard to disputes procedure obligations, and in some instances to Commission directions and recommendations, is not reasonably justifiable. Such industrial action is symptomatic of a kind of industrial conflict that no longer commands a respectable place in Australian industrial relations, if it ever had one. Where it occurs, as it has here, in an industry of national importance, a public interest is attracted in restraining further occurrences of such action. That is not to deny the reality and extent of the Company's private interest

\footnotetext{
${ }^{1}$ The infamous march on Parliament House in August 1996 accounted for two strike days, after the employer refused to release 10 per cent of its workforce on full pay to attend the rally.
} 
in seeking to constrain disregard of the dispute settlement procedure. That relative private interest augments, but must also be balanced with, the public interest in seeking to bring about a workplace level arrangement consistent with the objects of the Act.

This approach demonstrates that the AIRC is prepared to issue orders to prevent irresponsible industrial action.

The AIRC reserved consideration of actual or probable industrial action engaged in on a national, district or Statewide basis. This decision assumed testcase proportions and has provided significant guidance as to the exercise of the AIRC's powers under $\mathrm{s} .127$ by formulating a test for determining whether an order should be issued. That test evaluates the character of the industrial action for the purposes of establishing whether, in the AIRC's view, the industrial action is illegitimate to a degree that the commencement or continuation of it should be subject to a direction, causing it to be unlawful. In applying its discretion, the scheme of the Workplace Relations Act and the treatment of industrial action should be taken into account by the AIRC. This involves the division of industrial action into three categories:

- Protected industrial action: for the purposes of furthering and supporting claims made in enterprise bargaining and after complying with statutory requirements for establishing an immunity for industrial action.

- Unlawful industrial action: action directly contrary to a statutory provision or order of the AIRC under s.127.

- Unprotected action which, although generally inconsistent with the scheme of the Workplace Relations Act, is not automatically unlawful but may be rendered so by an order of the AIRC.

The approach of the AIRC in relation to national statewide or district stoppages was tested in October 1997 during an extended stoppage at the same Hunter Valley coal mine as subject to the s.127 test-case decision. The unions involved in that mine had engaged in protected industrial action in pursuit of a certified agreement. A six-week strike was followed in early September 1997 by another stoppage when further negotiations and conciliation by the AIRC failed to lead to an agreement. In response to obstructive picketing activity, Coal \& Allied sought a certificate from the AIRC permitting it to take common-law action against the unions. The certificate was granted and an appeal by the unions against the granting of the certificate was dismissed by a full bench. The Construction, Forestry, Mining and Energy Union (CFMEU) thereupon called an immediate 72-hour stoppage (without consulting the union members concerned) at approximately 40 mines in the Northern District of

${ }^{2}$ Coal and Allied Operations Pty Ltd $v$ Automotive Food Metals Enginecring Printing and Kindred Industries Union (1997) 73 IR 311. 
New South Wales, almost none of which had a relationship with Coal \& Allied or Rio Tinto. Immediate applications were made to the AIRC for orders under s.127, and a hearing began at the same time as the stoppage began. At the conclusion of the hearing that day, Commissioner Harrison indicated that he intended to issue orders as sought by the employers but before doing so would await the outcome of a meeting between the premier of New South Wales, the unions, and Coal \& Allied. When the matter resumed the following morning the unions indicated that they had cut short their 72-hour strike and would be arranging for a return to work later that day. In the light of that advice, the Commission decided not to issue the orders.

Non-enforcement of orders. In two cases, Justice Marshall of the Federal Court declined to enforce s. 127 orders. In one case, the AIRC made an order that the Health Services Union of Australia (Victoria No. 1 Branch) and its members employed by the Inner and Eastern Health Care Network 'are directed to cease current bans and limitations' and 'further directed not to engage in, commence or resume industrial action in connection with the issue of market contestability'. Justice Marshall refused to enforce the order because in naming a branch of a union the order was referring to a legal nullity and in any event the order was too vague and uncertain to enforce. He said:

It is critical for the purposes of proceedings in the Court pursuant to Section 127(6) and (7) of the Act that the order made by the Commission under Section 127(1) of the Act be a valid order. It is also critical that such an order clearly identify the persons on whom it is binding and the precise conduct which it seeks to prohibit. ... A direction to cease 'current bans and limitations' leaves room for later debate as to what the extent of such bans and limitations were at the time of the order. Similarly, a direction 'not to engage in, commence or resume industrial action in connection with the issue of market contestability' leaves room for debate as to whether any such action is so connected let alone 'industrial action'.

The second case concerned an order made against employees covered by various manufacturing awards in the face of widespread industrial action in protest at Victorian government's reforms of workers compensation. Justice Marshall found that the terms of the order did not adequately specify the relevant awards and criticised the employer representatives for seeking to have the AIRC remedy the defect in its order. Justice Marshall's decision allowed the stoppage to occur accompanied by a decision that the order made by the AIRC was invalid and unenforceable. Experiences such as this have given rise to considerable frustration amongst employers as to the utility of seeking orders under s.127.

\footnotetext{
3 Inner and Eastem Healthcare Network v HSUA VG619/97 (unreported 11 November 1997). 


\section{Concluding Comments}

In some cases, $s .127$ has been shown to be capable of limiting illegitimate industrial action. By 21 November 1997, 236 applications under s.127 had been made. According to the Minister for Workplace Relations, Mr Peter Reith (1997), most resulted in a return to work without an order being required; and the AIRC made only 24 orders. Given the particular circumstances involved, the issuance of orders has been hardly surprising or controversial. But even in these cases there are grounds for concern. Significant delays, the cost and inconvenience of lengthy litigation and the reluctance to issue and enforce orders other than in exceptional circumstances sustain a pattern of imbalance within the Australian industrial system.

Despite the intent of the legislature, the practical application of laws can lead to different results. In one example, Deputy President Duncan ${ }^{5}$ in December 1997 refused to issue orders sought by Telstra even though he found that the industrial action concerned was not protected. The union had failed to comply with the notice requirements for protected industrial action in circumstances where it intended to take industrial action without specific notice as to timing and its nature, in order to cause maximum damage to Telstra's business in the Customer Service area.

Effective remedies against irresponsible industrial action should be freely available to all businesses, regardless of their size and resources. Procedures should be swift and effective, and orders should be made unless there is some clear justification for the industrial action concerned. Given the range of options available for resolving disputes, industrial action other than action properly in compliance with the requirements for protected action in enterprise bargaining should rarely be considered justifiable.

Where discretions are vested in tribunals and courts and there is limited guidance in the legislation as to how the discretion is to be exercised, there is a tendency for historically generated value judgments to influence unduly the exercise of that discretion. Further reform is needed in this area to ensure that irresponsible industrial action ceases to be as prevalent as it has been at Australian workplaces.

\section{References}

Creighton, B. (1991), 'Enforcement in the Federal Industrial Relations System: An Australian Paradox', Australian Joumal of Labour Law4: 197-225.

Reith, P. (1996), Better Pay for Better Work: The Federal Coalition's Industrial Relations Policy, Parliament House, Canberra (18 December).

(1997), Press Release, Parliament House, Canberra (30 December).

Sweeney, K. \& J. Davies (1997), 'International Comparisons of Labour Disputes in 1995', Labour Market Trends, April (UK Government Statistical Service).

The author acknowledges the helpful comments of two anonymous referees.

${ }^{5}$ Telstra Corporation Led and CPSU Print No. P7102. 